\title{
The Inheritance of Multicultural Values in The Community of Kampung Gedang, Banjarmasin City, South Kalimantan
}

\author{
Yusuf Hidayat \\ Sociology Anthropology Education Department \\ Faculty of Teacher Training and Education \\ Univeritas Lambung Mangkurat \\ Banjarmasin, Indonesia
}

\begin{abstract}
This paper is the result of research that examines the inheritance of multicultural values in the community of Kampung Gedang, Banjarmasin. This community is a unique community in Banjarmasin because in this community lives in harmony four ethnic groups that have different socio-cultural: Madurese ethnic known as a temperamental ethnic, Chinese ethnic known as an exclusive ethnic and Banjarese ethnic as a native ethnic in Banjarmasin city. They have succeeded in creating multicultural values so that they can live harmoniously and can maintain it from generation to generation up to present. This shows that there is an effort to inherit values of multiculturalism effectively so that these values are held firmly by all elements of society in Kampung Gadang up to present. Therefore, this research is aimed to get deep information about the pattern of inheritance of multicultural values by Kampung Gadang community. This research used qualitative research method and has been implemented in Kampung Gedang, Banjarmasin city. Six informants who were determined purposively have been interviewed for this purpose. They consisted of community leaders, Banjarese ethnic, Madurese ethnic and Chinese ethnic. This study found that the process of inheriting cultural values by the Kampung Gedang community was conducted in various ways: first, strength of family institutions as agents in the socialization of multicultural values; second, communal institutions owned by the Madurese as immigrants ethnic in socializing the values of togetherness; third, religious institutions that create a peaceful atmosphere by instilling an attitude of inter-cultural tolerance in various religious activities.
\end{abstract}

Keywords - inheritance, multicultural values, ethnic group

\section{INTRODUCTION}

Recent community-to-person relationships have gained tremendous attention due to the emergence of various issues of interstate clashes or known 'SARA' (religious and racial tribes) in society. This issue developed along with the emergence of movements of some groups of people who carried the banners of certain groups and feared would destroy the joints of life together which became the foundation of the Unitary State of Indonesia.

The issue of weakening the values of togetherness has prompted the government and some elements of society to encourage a national movement that seeks to uphold the diversity of Indonesia. One of the government's efforts in strengthening the unity and unity of the nation is the excavation of the society's values that can be used as a reference for all components of society in building a together life. For that reason, studies that explore values in different parts of Indonesian society can be used as a reference to achieve these interests.

One region that has a creation of harmony between religious communities is in the Kampung Gedang Banjarmasin City. In this area, people with diverse ethnic backgrounds of Banjarese, Javanese, Madurese, and Chinese can live harmoniously even though they have different cultures. They can nurture a common life in ethnic diversity up to now. The way they care for togetherness teaches about the values of multiculturalism so that these values are sustainable needs to be studied more deeply. Therefore, this study seeks to gain a deep understanding of the care and inheritance of multicultural values which can live harmoniously and can serve as one of the cultural heritage that can be preserved. As a result, the model of multicultural society can be preserved up to the next generations.

This study will examine how do the efforts of people of Kampung Gedang maintain and preserve the multicultural values to their next generation and to create harmony between them?

\section{MethOD}

This research used qualitative research methods to gain a deep understanding of the inheritance of multicultural values. 
TABLE 1. ETHNIC POPULATION BY 2016

\begin{tabular}{|c|c|c|c|}
\hline No. & Ethnic Name & Amount & Percentage \\
\hline 1. & Madurese & 2.663 & $40 \%$ \\
\hline 2. & Banjarese & 1.712 & $25 \%$ \\
\hline 3. & Chinese & 1.059 & $16 \%$ \\
\hline 4. & Javanese & 747 & $11 \%$ \\
\hline 5. & Other & 536 & $8 \%$ \\
\hline & Total & 6717 & $100 \%$ \\
\hline
\end{tabular}

Source: Kampung Gadang Profile 2016: 20

This qualitative research used deep, long and open interviews. Such a way, allowed researchers to provide broad opportunities for informants to express their views according to the perspectives they believe in.

This research was conducted in Kampung Gedang, Banjarmasin City, and South Kalimantan. This region is an area inhabited by several ethnicities namely Madurese, Banjarese, Chinese, and Javanese who live in harmony with their cultural differences. This research determined the informant by way of snowball, the informant selected based on information from the previous informant who appointed someone who deserved to be interviewed. Therefore, the determination of this informant started from a key informant who was considered a very master of this research problem.

For the purposes of data collection, the researcher has conducted in-depth interviews by using interview guides to select informants while for secondary data; the researcher looked for various parties who had relevant data required.

The results of the interview were then recorded. There were two notes in the data recording: descriptive notes and reflective notes. Descriptive notes presented detailed events rather than just a summary, and these notes were not evaluations. Reflective notes addressed the minds, ideas, and concerns of researchers. On this note, researchers commented on and analyzed what the informant's statement said.

These notes, in which subsequent interview transcripts were classified according to the relevant themes of a common theme, were then classified again in a more specific theme. However, before the classification of data, there were several steps taken. First, made a categorization of the problem or find and compile the code. These categories certainly used a certain mindset. Second step is arranged the sequences of the study.

\section{RESULT}

\section{A. Kampung Gedang: A Harmony in Ethnic Diversity}

Kampung Gedang is the name of the origin of Kelurahan Gadang which is administratively one of the regions in the district of Center of Banjarmasin. This region is a unique area in the city of Banjarmasin because of its diverse ethnic backgrounds that have been formed very long since the Dutch East Indies. The ethnic background of the residents of Kampung Gedang are Madurese ethnic, Javanese ethnic, Chinese ethnic and the native Ethnic, Banjarese ethnic as shown in table 1 below.

Table 1 above shows the diversity of ethnic Kampung Gadang resident background. There are four dominant ethnic groups who live in Kampung Gedang namely Madurese as majority ethnic group as many as 2.663 (40\%) followed by ethnic Banjar as a native ethnic in this region as many as 1,712 (25\%), Chinese ethnic 1,059 (16\%) and Javanese ethnic as much as $747(11 \%)$ and the rest is $536(8 \%)$ people with other ethnic backgrounds namely, Sundanese, Bugis and Batak. Ethnic background with a series of different accompanying cultures makes the community of Kampung Gedang as a multicultural society.

Although they are culturally different, yet they can co-exist harmoniously without any significant conflict up to now. The harmony of the villagers happens because they respect each other and tolerate the cultural differences between them. Banjar people, as indigenous ethnic, accept the presence of Madurese, Chinese and Javanese. Immigrants' ethnic appreciate the Banjar people as the native of Kampung Gedang. The harmony of Kampung Gedang residents can be seen from the relatively condition of the region that there is never any ethnic conflicts, a religious celebration which is respected by all members of the community, and citizens attending the meeting when there is the death of all the different ethnics. They have together life based on respect for different cultures and respect for the existence of different cultures. These values are preserved by all villagers of Kampung Gedang so that this kampung's harmony can be maintained up to now.

\section{B. Inheritance of Multiculturalism's Values}

Multicultural values in the community of Kampung Gedang can be maintained well up to now because these values are embedded in all components of the people of Kampung Gedang from several generations up to now. The continued strength of multicultural values in the Kampung Gedang is their success in preserving and inheriting those values in several generations of people. This inheritance effort is done by all components of society by using the various social organization of society such as family, and organization of certain ethnic and religious organization.

The family is the initial foundation for the formation of the character of society including the growth of the soul of tolerance, one of the necessary attitudes to create a harmonious life in society. The people of Kampung Gedang understand the meaning of the family for the formation of community character. They teach about how to live together in a diverse society. As expressed by Oce, one of Chinese ethnic citizens of Kampung Gadang:

"Saya biasanya mengajari anak-anak bahwa kita sesama manusia itu harus baik, kalau bisa saling tolong menolong. Habis tu ibu contohkan aja kayapa seharusnya bermasyarakat. Ketika saya membantui keluarga siapa disini ibu bawai inya, jadi inya tahu lawan orang-orang disini. 
(I usually teach my children that we should be good with other human beings, it will be better if we can help each other. After that I give an example how to create well relationships with the community. When I help anyone, surely my son is invited. So, he knows the people here)

The role of the family in growing the values of multiculturalism is also recognized by $\mathrm{Mr}$. $\mathrm{H}$. Asmad, chairman of KAWAMA South Kalimantan. He, as head of the household, always cautions his son to be always good at introspection when dealing with others as presented by $\mathrm{Mr}$. $\mathrm{H}$. Asmad as follows:

\section{"amun inya handak bejalan tuh biasanya abah padahi "ajelen jil bender". Kalau berjalan itu harus hati-hati" (If he wants to walk I always say: “ajelen Jil Bender"'it means that if he goes, he should be careful)}

Mr. H. Asmad always cautions his son when traveling should be "ajelen jil bender" (when he goes, he should be careful) means that when we walking we should see how the character of people so that we can relate well with people because we understand the character of others. In addition, when we walk, we should put ourselves in accordance in where we passed and we do not follow a variety of activities that are not clear. By upholding this doctrine, according to Mr.H, Asmad, we will get a peaceful life as they feel in Kampung Gedang.

In addition to a family, the most important thing in disseminating the way of together life to create harmony is the interest of ethnic groups to teach about this in their group. One of these roles is implemented by Madurese Concord (KAWAMA), which is chaired by Mr. H. Asmad. They often do guidance to newcomers who are new Madurese who come to Banjarmasin and live in Kampung Gedang. This organization plays an important role in the development of Madurese especially the new people because it is often complained by some non-Madurese about the existence of newcomers' population as expressed by Oce, a resident of Chinese:

"Cuman kadang-kadang memang pendatang (yang baru datang) itu kurang bisa meumpati adat yang sudah ada, lalu biasanya jadi konflik".

(It is just that sometimes there are newcomers who do not obey the rules that already exist so often lead to conflict)

Oce's statement above show how the behaviour of newly arrived Madurese often does not heed the rules of living together in Kampung Gedang and often causes some problems in the together life. Complaints of the above Chinese people, responded by one of the Madurese community leaders in Kampung Gadang, Mr. H. Asmad through the organization he leads by carrying out various activities undertaken by the Madurese community

in which embedded values of living together. This activity is done every month even at times where many Madurese come in the month of Shawal and in the month of DzulHijjah, this activity is intensified. In this activity, H. Asmad always advises that Madurese should always keep their code:

"Ulun selalu memadahi mereka "Cak to Karan jieh" yang artinya jangan pina handak bekelahian". (I always tell them "Cak to karan jieh" means do not do fighting)

The message of "Cak to karan jiieh" or do not do a fight is a phrase that always be communicated to the Madurese community by its leaders. This message is of course also communicated in the arisan activity of "KAWAMA" whose members are Madurese. This activity is also filled with the appearance of Madurese cultural art and recitation which among the materials contain of various messages, especially the behaviors that the Madurese live side by side with other communities, especially residents of Kampung Gedang.

The establishing of multicultural values in the community is also done by religious teachings which are held in Kampung Gadang. In this activity, the speakers usually fill some materials about the implementation of religious teachings and the relationship between someone to other humans, and teach about the importance of harmony life as expressed by Ustadz Yustan:

"Of course, every Wednesday night in the syiar Islam which named "Kaffah" religious teaching always inserts about understanding of our attitude in diversity. As the result, it can be said in every recitation I always tuck about the attitude of tolerance in multicultural itself."

For Ustad Yustan, the establishing of equality's values and togetherness are always being communicated in various recitation activities that are always interspersed to the delivery of the ways of living together with various rules in together life.

\section{DISCUSSION}

The Kampung Gedang community is a plural society consisting of several ethnic groups: the Madurese, Banjar ethnic, Chinese ethnic. They live together harmoniously despite of different cultural backgrounds. The harmony is nurtured because there is a clear limitation on which cultural values of each ethnic and universal value that should be shared.

The societies of different cultural backgrounds, who are universally held universal norms, are referred to multicultural societies; as defined by Rex [1]:

"Multicultural society is to be understood as one of where the public spheres, incorporating such as areas of politics, economics, professional education, and law would be based on single and universal principles whereas the private spheres, which involves such as areas of religious beliefs, moral education, and primary socialization would allow for greater diversity between ethnic groups." 
Increased growth of conflicts involving some ethnicities in Indonesian society after Orde Baru do not affect the pattern of social relations that occur in Kampung Gedang, Banjarmasin. Ethnic conflict between Madurese ethnic and some other ethnicities in Kalimantan such as Dayak in Central Kalimantan and Malay in Sambas does not spread to the pattern of social relations between Madurese, Banjar, Chinese and Javanese. They always live together up to now. This shows that they can preserve the values of multiculturalism in their lives and hold the norms of life among different ethnic groups firmly.

The preservation of the value of multiculturalism by society is a form of multicultural education as expressed by Gorski [2] (who said that multicultural education can include three types of transformation; self-transformation, school transformation, and teaching learning and community transformation.

Transformation of society in multicultural education in the society of Kampung Gedang has an important role in the preservation, values, and attitudes that must be owned by multicultural society. All components of the community in Kampung Gedang maintain multiculturalism in the community through families, ethnic groups of customary organizations formed by some ethnic leaders and religious organizations. They conduct community coaching according to their respective capacities so that the values of multiculturalism have become an important part of their live to create harmony among the Kampung Gedang societies.

These groups have an important role in conducting socialization which according to Berger and Luckmann [3] is one of the important factors in the internalization of social values, one of the three moments of social reality construction. The process of internalization is one of the important processes in instilling social values into a personality of each member of society that will shape their subjective awareness. This subjective awareness is important to determine the direction and motion of their behaviours in their daily life which will ultimately form into their collective consciousness to preserve and maintain these values which in the future will also be passed on to the next generation and will also be adapted to the development community. Therefore, the values of multiculturalism in Kampung Gedang society will be sustainable and will become a cultural heritage that is very important in maintaining the solid state of Indonesia Unity in Diversity.

\section{CONCLUSION}

The people of Kampung Gedang are ethnically diverse, the ethnic of Madurese as the majority ethnic, the ethnic of Banjar, the ethnic of Chinese and the Javanese ethnic. Although they have different cultures, they can live together harmoniously. This harmony is created because the people of Kampung Gedang have different cultural values, have shared values that can bridge their cultural differences, and have patterns of attitude that respects differences and respect for other different groups. These values are well preserved up to now because the process of transforming the values of their future generations can work well. This process is done through: first, the strength of family institutions as agents in the socialization of multicultural values; second, communal institutions owned by the Madurese as immigrants' ethnic in socializing the values of togetherness; third, religious institutions that create a peaceful environment by instilling an attitude of inter-cultural tolerance in various religious activities.

\section{REFERENCES}

[1] J. Rex, Ethnic Minorities and modern nation state, London: Mcmillan, 2004

[2] P. Gorski, Six critical Paradigm Shifd for Multicultural Education and the question we should be asking, retrieve from http.edchange.org/multicultural, on $1^{\text {st }}$ July 2011

[3] P. L. Berger, and T. Luckman, Tafsir Sosial atas Kenyataan: Risalah tentang Sosiologi Pengetahuan, Terjemahan Hasan Basari, Jakarta: LP3ES, 1990. 